\title{
Analisis Pengaruh Persepsi Kualitas dan Persepsi Nilai Terhadap Kepuasan Konsumen dan Minat Beli Ulang
}

(Studi pada Konsumen Indomaret di Kecamatan Depok Sleman)

Tomi Dwi Cahyono dan Al- Bari

Fakultas Ekonomi Pascasarjana Universitas Islam Indonesia

E-mail: tomy.dche@gmail.com

\begin{abstract}
Abstrak
Penelitian ini bertujuan mengetahui pengaruh persepsi kualitas dan persepsi nilai yang diliputi nilai fungsional, nilai emosional dan nilai sosial terhadap kepuasan konsumen dan minat beli ulang pada konsumen Indomaret di Kecamatan Depok Sleman. Populasi dalam penelitian ini adalah seluruh konsumen yang berbelanja pada Indomaret yang berada di wilayah Kecamatan Depok Sleman yang berjumlah 9 Indomaret. Sedangkan sampel pada penelitian ini sebagian pembeli yang berbelanja di sejumlah Indomaret yang ada di wilayah Kecamatan Depok Sleman yang berjumlah sebanyak 100 orang dengan teknik pengambilan sampel metode accidental sampling.. Data yang digunakan dalam penelitian ini adalah data primer yang bersumber dari penyebaran kuesioner kepada responden penelitian. Penelitian ini meliputi variabel persepsi kualitas produk, persepsi nilai yang meliputi (persepsi nilai fungsional, persepsi nilai emosional, dan persepsi nilai sosial), kepuasan, dan minat beli ulang.Untuk pengujian hubungan antara beberapa variabel tersebut digunakan analisis Structural Equation Model (SEM) dengan menggunakan bantuan software PLS (Partial Least Square). Hasil analisis data menyimpulkan bahwa: (1) Persepsi kualitas berpengaruh signifikan dan positif terhadap persepsi nilai fungsional; (2) Persepsi kualitas berpengaruh signifikan dan positif terhadap persepsi nilai emosional; (3) Persepsi kualitas berpengaruh signifikan dan positif terhadap persepsi nilai sosial; (4) Persepsi nilai fungsional berpengaruh signifikan terhadap kepuasan konsumen; (5) Persepsi nilai emosional berpengaruh signifikan terhadap kepuasan konsumen; (6) Persepsi nilai sosial berpengaruh signifikan.
\end{abstract}

Kata Kunci : Persepsi, Kualitas Produk, Nilai Fungsional, Nilai Emosional, Nilai Sosial, Kepuasan, Minat Beli Ulang

\section{PENDAHULUAN}

Dinamika persaingan bisnis ritel pada saat ini mengharuskan setiap perusahaan yang bergerak di bidang ini untuk senantiasa melakukan berbagai strategi agar dapat merebut hati konsumen. Perusahaan harus dapat menerapkan strategi yang tepat dalam menarik minat konsumen untuk melakukan pembelian ulang. Pertumbuhan industri ritel ditandai dengan semakin berkembangnya pasar modern di wilayah perkotaan dan pedesaan. Hadirnya sejumlah minimarket atau toko serba ada tampak menghiasi di sejumlah pasar modern tersebut.

Seiring perkembangan jaman, keberadaan bisnis ritel atau eceran di tengah-tengah masyarakat menjadi semakin penting. Hal ini disebabkan masyarakat lebih cenderung memilih sagala sesuatunya yang mudah dan cenderung praktis. Yang dulunya masyarakat berbelanja di pasar tradisional, sekarang mereka lebih cenderung berbelanja di pasar modern. Karena berbelanja di pasar modern juga jauh lebih menarik dan efisien waktu. Selain karena tempatnya bersih, para konsumen juga akan lebih mudah untuk mencari barangbarang yang mereka perlukan dengan harga yang terjangkau sesuai kondisi keuangan mereka, dan disisi lain pasar modern juga selalu berusaha menjaga kualitas produknya. Pasar modern itu juga tampil dengan berbagai macam bentuk dan ukuran, contohnya mall, department store, shopping center, dan hypermarket.

Minimarket Indomaret adalah salah satu perusahaan ritel yang bergerak dalam bidang penjualan produk-produk seperti: perlengkapan rumah tangga, perlengkapan sekolah dan kantor, kebutuhan bayi dan 
anak, makanan dan minuman, produk kecantikan, dan sebagainya. Sebagai perusahaan ritel, tentunya Indomaret memiliki preferensi tersendiri di dalam persaingan di antara pebisnis ritel yang ada. Sebagai sebuah perusahaan ritel tentunya Indomaret juga telah berupaya menerapkan strategi yang tepat guna menarik minat konsumen untuk melakukan pembelian ulang kembali di minimarket tersebut.

Minat beli ulang (repurchase intention) merupakan suatu komitmen konsumen yang terbentuk setelah konsumen melakukan pembelian suatu produk atau jasa, komitmen ini timbul karena kesan positif konsumen terhadap suatu merek, dan konsumen merasa puas terhadap pembelian tersebut (Hicks et al, 2005). Butcher (2005) berpendapat bahwa minat konsumen untuk membeli ulang adalah salah satu ukuran dari keberhasilan dari suatu perusahaan. Definisi ini menjelaskan bahwa semakin tinggi kepuasan konsumen akan menyebabkan makin tingginya keputusan untuk melakukan pembelian lagi.

Minat untuk membeli kembali suatu produk atau jasa akan muncul ketika pelanggan merasa bahwa jasa yang diterimanya bisa memberikan kepuasan terhadap diri pelanggan tersebut. Bila pelanggan puas pada pembelian pertama, maka pembelian berikutnya cenderung akan dilakukan secara berulang-ulang pada satu merek, sehingga pengambilan keputusan tidak lagi diperlukan karena pelanggan telah mengetahui secara mendalam mengenai merek tersebut Tatik ( 2008), sehingga dapat diambil kesimpulan bahwa pelanggan yang merasa puas atas pembelian yang dilakukan maka pelanggan akan melakukan pembelian kembali. Penelitian Tsiotsou (2005) menyatakan kepuasan secara langsung memiliki pengaruh positif dan signifikan terhadap minat beli ulang konsumen.

Untuk mencapai kepuasan pelanggan, tentunya banyak hal yang mempengaruhi pelanggan merasa puas atas produk/jasa yang akan dikonsumsinya. Salah satu faktor tersebut adalah mengenai persepsi nilai pelanggan, diyakini bahwa nilai yang dipikirkan pelanggan akan memberikan pengaruh terhadap tingkat kepuasan seorang pelanggan terhadap produk atau jasa yang akan digunakannya. Menurut Sweeney \& Soutar (2001), persepsi nilai pelanggan diklasifikasikan kedalam tiga dimensi yaitu nilai fungsional, nilai emosional, dan nilai sosial. Nilai fungsional didefinisikan sebagai nilai yang diperoleh dari atribut produk yang memberikan kegunaan (utility) fungsional kepada konsumen, nilai ini berkaitan langsung dengan fungsi yang diberikan oleh produk atau layanan kepada konsumen. Selanjutnya nilai emosional merupakan utilitas yang berasal dari perasaan atau efektif atau emosi positif yang ditimbulkan dari mengkonsumsi produk. Jika konsumen mengalami perasaan positif (positive feeling) pada saat membeli atau menggunakan suatu merek, maka merek tersebut memberikan nilai emosional. Dan kemudian nilai sosial adalah utilitas yang didapat dari kemampuan produk untuk meningkatkan konsep diri-sosial konsumen. Nilai sosial merupakan nilai yang dianut oleh suatu konsumen, mengenai apa yang dianggap baik dan apa yang dianggap buruk oleh konsumen. Penelitian Rhee \& Ryu (2012) menemukan bahwa persepsi nilai memberikan kontribusi yang signifikan dalam mempengaruhi kepuasan konsumen, Choi \&Kim (2013) yang menyimpulkan bahwa persepsi nilai yang meliputi nilai fungsional, nilai emosional, dan nilai sosial memberikan pengaruh positif dan signifikan terhadap kepuasan konsumen.

Sejalan dengan teori dan beberapa hasil penelitian di atas, maka dapat dikatakan adanya korelasi antara variabel persepsi kualitas, persepsi nilai, kepuasan konsumen dan minat beli ulang. Hal ini diperkuat dengan beberapa penelitian, diantaranya adalah Yuriansyah (2013) yang menyatakan adanya pengaruh persepsi kualitas pelayanan, nilai produk, dan fasilitas secara simultan terhadap kepuasan. Puspitasari (2006) menemukan bahwa terdapat pengaruh persepsi kualitas terhadap kepuasan pelanggan dan minat beli ulang konsumen. Penelitian (Scoot \& Davis, 2003) menunjukkan hasil bahwa persepsi kualitas dan kepuasan konsumen berpe-ngaruh terhadap repurchase intention. Penelitian Wisnalmawati (2005) menunjuk-kan hasil bahwa persepsi 
kualitas dan kepuasan berpengaruh terhadap minat pembelian ulang dan persepsi kualitas berpengaruh terhadap minat pembelian ulang melalui kepuasan sebagai variabel moderating. Tsiotsou (2005) menunjukkan hasil bahwa persepsi kualitas dan kepuasan berpengaruh terhadap minat pembelian ulang.Menurut Choi \& Kim (2013) yang menyimpulkan bahwa persepsi kualitas berpengaruh positif dan signifikan terhadap persepsi nilai yang meliputi nilai fungsional, nilai emosional, dan nilai sosial, selanjutnya persepsi nilai yang meliputi nilai fungsional, nilai emosional, dan nilai sosial juga berpengaruh positif terhadap kepuasan konsumen dan minat beli ulang.

Berdasarkan uraian latar belakang diatas, penulis tertarik untuk melakukan penelitian mengenai pengaruh persepsi kualitas dan persepsi nilai terhadap kepuasan konsumen dan minat beli ulang pada konsumen Indomaret di Kecamatan Depok Sleman.

\section{Kajian Teoritik Dan Hipotesis 1.1 Persepsi Kualitas}

Pemahaman terhadap persepsi dan proses yang terkait sangat penting bagi pemasar dalam upaya membentuk persepsi yang tepat. Terbentuknya persepsi yang tepat pada konsumen menyebabkan mereka mempunyai kesan dan memberikan penilaian yang tepat. Berdasar persepsi inilah konsumen, tertarik dan membeli. Hurriyati (2005) menyatakan persepsi adalah proses yang dilalui orang dalam memilih, mengorganisasikan, dan menginterpretasikan informasi guna membentuk gambaran berarti mengenai dunia.Persepsi kualitas (perceived quality) dapat didefinisikan sebagai persepsi pelanggan terhadap keseluruhan kualitas atau keunggulan suatu produk atau jasa layanan berkaitan dengan apa yang diharapkan oleh pelanggan (Cho \& Kim, 2013).

Produk atau jasa yang berkualitas tentunya akan mempengaruhi cara pandang konsumen terhadap nilai produk/jasa tersebut. Tsiotsou (2005) mendefinisikan persepsi kualitas sebagai penilaian konsumen tentang keunggulan keseluruhan produk atau superioritas. Lovelock \& Wright (2007) menyatakan kualitas pelayanan harus dimulai dari kebutuhan konsumen dan berakhir pada persepsi konsumen. Persepsi konsumen terhadap kualitas layanan itu sendiri merupakan penilaian menyeluruh konsumen atas keunggulan suatu layanan. Terdapat 5 (lima) determinan kualitas jasa yang dapat dirincikan (Tjiptono \& Gregorius, 2005), yaitu keberwujudan (tangible), keandalan, (reliability), daya tanggap (responsiveness), jaminan (assurance) dan empati (empathy).

Persepsi kualitas merupakan salah satu indikator mengenai baik tidaknya kualitas suatu produk/jasa, persepsi kualitas erat kaitannya dengan pembentukan persepsi pelanggan, dengan demikian bagi perusahaan yang ingin tetap mempertahankan eksistensinya dan memenangkan persaingan bisnis serta menarik perhatian pelanggan senantiasa memberikan pelayanan yang berkualitas serta fasilitas pendukung yang sesuai dengan harga yang telah dibayar oleh pelanggan atau berusaha untuk memenuhi kebutuhan serta mewujudkan harapan mereka. Rangkuti (2003) menyatakan nilai produk sebagai pengkajian secara menyeluruh manfaat dari suatu produk, didasarkan persepsi pelanggan atas apa yang telah diterima oleh pelanggan dan yang telah diberikan oleh produk tersebut.

Persepsi kualitas yang tinggi menunjukkan bahwa melalui penggunaan dalam jangka waktu yang panjang, konsumen memperoleh diferensiasi dan superioritas dari merek tersebut. Mengidentifikasikan persepsi kualitas sebagai komponen dari nilai merek dimana persepsi kualitas yang tinggi akan mengarahkan konsumen untuk memilih merek tersebut dibandingkan dengan merek pesaing (Cho \& Kim, 2013). Persepsi kualitas yang dirasakan oleh konsumen berpengaruh terhadap kesediaan konsumen tersebut untuk membeli sebuah produk. Ini berarti bahwa semakin tinggi nilai yang dirasakan oleh konsumen, maka akan semakin tinggi pula kesediaan konsumen tersebut untuk akhirnya membeli (Cho \& Kim, 2013).

Produk atau jasa yang berkualitas tentunya akan mempengaruhi cara pandang konsumen terhadap nilai produk/jasa tersebut. Menurut Tsiotsou (2006) persepsi kualitas didefinisikan sebagai penilaian 
konsumen tentang keunggulan keseluruhan produk atau superioritas. Lovelock \& Wright (2007) menyatakan kualitas pelayanan harus dimulai dari kebutuhan konsumen dan berakhir pada persepsi konsumen. Hal ini berarti bahwa citra kualitas layanan yang baik bukanlah berdasarkan sudut pandang atau persepsi pihak penyedia jasa, melainkan berdasarkan pada sudut pandang atau persepsi konsumen. Kualitas yang dirasakan didefinisikan sebagai penilaian konsumen terhadap keseluruhan keunggulan produk Tjiptono (2008). Apabila layanan yang diterima atau dirasakan sesuai dengan yang diharapkan konsumen, maka kualitas layanan dipersepsikan sebagai kualitas ideal, tetapi sebaliknya jika layanan yang diterima atau dirasakan lebih rendah dari pada yang diharapkan, maka kualitas layanan dipersepsikan buruk.

Persepsi kualitas mencerminkan perasaan pelanggan yang tidak nampak dan secara menyeluruh mengenai suatu merek. Akan tetapi, biasanya persepsi kualitas didasarkan pada dimensi-dimensi yang termasuk dalam karakteristik produk tersebut dimana merek dikaitkan dengan hal-hal seperti keandalan dan kinerja. Lima dimensi kualitas jasa untuk memahami harapan dan persepsi konsumen terhadap kualitas jasa tersebut adalah : 1) Keandalan (Reliability), kemampuan untuk melaksanakan jasa yang dijanjikan dengan tepat dan terpercaya; 2) Ketanggapan (Responsiveness) kemauan perusahaan untuk membantu pelanggan dan memberikan jasa dengan cepat; 3) Keyakinan (Assurance), pengetahuan dan keramahtamahan para karyawan serta kemampuan mereka untuk menimbulkan kepercayaan dan keyakinan.; 4) Empati (Empathy), syarat untuk peduli, memberi perhatian pribadi bagi pelanggan; dan 5) Berujud (Tangibles), penampilan fasilitas fisik (interior dan eksterior), peralatan, karyawan, dan media komunikasi (Cho \& Kim, 2013).

Seperti yang dikemukakan Kotler (2005) bahwa kualitas harus dimulai dari kebutuhan konsumen dan berakhir pada persepsi konsumen. Rangkuti (2003) menyatakan nilai produk sebagai pengkajian secara menyeluruh manfaat dari suatu produk, didasarkan persepsi pelanggan atas apa yang telah diterima oleh pelanggan dan yang telah diberikan oleh produk tersebut. Babin et al (2004) dalam penelitiannya mengembangkan sebuah model konseptual yang mewakili korelasi antara persepsi kualitas dan persepsi nilai, dan hasil penelitian ini menyimpulkan bahwa persepsi kualitas memiliki korelasi yang tinggi dengan persepsi nilai. Penelitian Adixio \& Saleh (2013) menunjukkan bahwa persepsi kualitas secara positif dan signifikan mempengaruhi nilai yang dipersepsikan. Hasil penelitian Choi \& Kim (2013) menyimpulkan bahwa persepsi kualitas berpengaruh positif dan signifikan terhadap persepsi nilai yang meliputi nilai fungsional, nilai emosional, dan nilai sosial.

\subsection{Persepsi Nilai}

Nilai yang dirasakan pelanggan (CPV Customer Perceived Value) adalah selisih antara penilaian pelanggan prospektif atas semua manfaat dan biaya dari suatu penawaran terhadap alternatifnya (Kotler \& Keller, 2009). Dewasa ini, pelanggan lebih terdidik dan berpengetahuan. Pelanggan mempunyai sarana (misalnya internet) yang memungkinkannya memverifikasi klaim perusahaan dan mencari alternative yang lebih unggul. Pelanggan cenderung memaksimalkan nilai dalam batasan biaya pencarian, pengetahuan, mobilitas, dan pendapatan. Pelanggan akan memperkirakan tawaran mana yang dapat memberi-kan nilai tertinggi yang akan membuat pelanggan bertindak atas dasar pemikiran tersebut. Sesuai atau tidaknya suatu penawaran dengan harapan akan mempe-ngaruhi kepuasan pelanggan dan besarnya probabilitas bahwa pelanggan akan membeli produk itu lagi. Dengan demikian, nilai yang dirasakan pelanggan didasarkan pada selisih antara apa yang didapatkan pelanggan dan apa yang pelanggan berikan untuk kemungkinan pilihan yang berbeda.

Tjiptono (2004) menekankan bahwa pemasaran berkaitan erat dengan upaya menciptakan dan memberikan nilai kepada pelanggan. Nilai pelanggan merupakan sebuah konsep yang hingga saat ini paling digunakan oleh pelaku bisnis. Konsep ini pada dasarnya sederhana dan dapat 
digunakan sebagai langkah awal perumusan strategi selanjutnya. Secara sederhana, nilai pelanggan dapat didefinisikan sebagai semua manfaat atau kualitas yang diperoleh oleh konsumen relatif terhadap pengorbanannya. Nilai pelanggan biasa didefinisikan sebagai total manfaat atau kualitas dibagi harga. Kotler \& Armstrong (2001) mendefinisikan nilai pelanggan sebagai perbedaan antara nilai yang dinikmati pelanggan karena memiliki serta menggunakan suatu produk dan biaya untuk memiliki produk tersebut. Menurut Sweeney \& Soutar (2001), persepsi nilai pelanggan diklasifikasikan kedalam tiga dimensi yaitu nilai fungsional, nilai emosional, dan nilai sosial.

\section{Nilai fungsional}

Nilai fungsional adalah nilai yang diperoleh dari atribut produk yang memberikan kegunaan (utility) fungsional kepada konsumen nilai ini berkaitan langsung dengan fungsi yang diberikan oleh produk atau layanan kepada konsumen.

\section{Nilai emosional}

Nilai emosional adalah utilitas yang berasal dari perasaan atau efektif atau emosi positif yang ditimbulkan dari mengkon-sumsi produk. Jika konsumen mengalami perasaan positif (positive feeling) pada saat membeli atau menggunakan suatu merek, maka merek tersebut memberikan nilai emosional. Pada intinya nilai emosional berhubungan dengan perasaan, yaitu perasaan positif apa yang akan dialami konsumen pada saat membeli produk.

\section{Nilai sosial}

Nilai sosial adalah utilitas yang didapat dari kemampuan produk untuk meningkat-kan konsep diri-sosial konsumen. Nilai sosial merupakan nilai yang dianut oleh suatu konsumen, mengenai apa yang dianggap baik dan apa yang dianggap buruk oleh konsumen.

Menurut Yang \& Peterson (2004), nilai pelanggan merupakan sebuah rasio dari manfaat yang didapat oleh pelanggan dengan pengorbanan. Perwujudan pengorbanan yang dilakukan oleh pelanggan sejalan dengan proses pertukaran adalah biaya transaksi, dan risiko untuk mendapatkan produk (barang dan jasa) yang ditawarkan oleh perusahaan. Ketika nilai yang dirasakan dari rasio yang dipersepsikan oleh pelanggan atas sejumlah pengorbanan ekonomi dengan produk yang ditawarkan perusahaan tidak sesuai dengan harapan pelanggan, maka akan memunculkan sikap tidak puas. Sebaliknya apabila sama atau melebihi harapan pelanggan maka pelanggan akan merasa puas.

Dewasa ini, konsep tujuan perusahaan telah bergeser dimana tujuan perusahaan tidak lagi semata-mata mencari laba, namun juga untuk memuaskan konsumen. Secara umum, kepuasan (satisfaction) adalah perasaan senang atau kecewa seseorang yang timbul karena membandingkan kinerja yang dipersepsikan produk (atau hasil) terhadap ekspektasi seseorang (Kotler \& Keller, 2009). Tjiptono (2008) mengungkapkan bahwa kepuasan konsumen merupakan evaluasi purna beli di mana alternatif yang dipilih sekurangkurangnya memberikan hasil (outcome) sama atau melampaui harapan konsumen, sedangkan ketidakpuasan timbul apabila hasil yang diperoleh tidak memenuhi harapan konsumen. Kotler (2005), kepuasan konsumen adalah tingkat perasaan seseorang setelah membandingkan antara kinerja yang dirasakan dengan harapan. Konsumen yang tidak merasa puas atas kualitas dan pelayanan yang diperoleh cenderung menimbulkan masalah, sebalik-nya apabila mereka puas maka akan tercipta hubungan yang baik dan harmonis. Hal ini akan menjadi dasar yang baik bagi terciptanya pembelian ulang dan terciptanya loyalitas konsumen yang akan menguntungkan perusahaan. Beralihnya konsumen disebabkan oleh kurang pekanya perusahaan dalam memberi pelayanan dan rasa tidak puas konsumen. Berdasarkan pengertian tersebut, maka dapat dinyatakan bahwa kepuasan konsumen adalah suatu tanggapan atau penilaian antara persepsi dan ekspektasi pembeli mengenai nilai suatu produk yang ditawarkan oleh produsen. Apabila kinerja berada di bawah harapan, maka konsumen akan kecewa. Sebaliknya, apabila kinerja 
sesuai dengan harapan, konsumen akan sangat puas.

Pembeli terpuaskan setelah membeli ataukah tidak sangat tergantung pada kinerja penawaran dalam hubungannya dengan ekspektasi pembeli. Begitu juga apakah pembeli mengintepretasikan adanya penyimpangan antara keduanya. Secara umum, kepuasan (satisfaction) adalah perasaan senang atau kecewa seseorang yang timbul karena membandingkan kinerja yang dipersepsikan produk (atau hasil) terhadap ekspektasi seseorang (Kotler \& Keller, 2009). Menurut Tjiptono (2008), kepuasan pelanggan adalah evaluasi purnabeli secara keseluruhan yang dilakukan pelanggan dengan membanding-kan persepsi atas kinerja produk dengan ekspektasi prapembelian.

Persepsi nilai pelanggan diyakini memberikan pengaruh terhadap tingkat kepuasan seorang pelanggan terhadap produk atau jasa yang akan digunakannya. Menurut (Yang \& Peterson, 2004), nilai pelanggan merupakan sebuah rasio dari manfaat yang didapat oleh pelanggan dengan pengorbanan. Menurut Sweeney \& Soutar (2001), persepsi nilai pelanggan diklasifikasikan kedalam tiga dimensi yaitu nilai emosional, nilai sosial, dan nilai fungsional. Hal ini sejalan dengan penelitian Luarn \& Lin (2003) yang menyatakan bahwa persepsi nilai memiliki hubungan yang positif dengan kepuasan konsumen. Penelitian Soegoto (2013), yang menyimpulkan bahwa persepsi nilai berpengaruh positip dan signifikan terhadap kepuasan konsumen. Rhee \& Ryu (2012) menemukan bahwa persepsi nilai memberikan kontribusi yang signifikan dalam mempengaruhi kepuasan konsumen. Yuriansyah (2013) menyatakan terdapat pengaruh persepsi nilaiproduk terhadap kepuasan pelanggan. Dan penelitian Choi \& Kim (2013) yang menyimpulkan bahwa persepsi nilai yang meliputi nilai fungsional, nilai emosional, dan nilai sosial berpengaruh positif dan signifikan terhadap kepuasan konsumen.

\subsection{Kepuasan}

Nilai yang dirasakan pelanggan (CPV Customer Perceived Value) adalah selisih antara penilaian pelanggan prospektif atas semua manfaat dan biaya dari suatu penawaran terhadap alternatifnya (Kotler \& Keller, 2009). Dewasa ini, pelanggan lebih terdidik dan berpengetahuan. Pelanggan mempunyai sarana (misalnya internet) yang memungkinkannya memverifikasi klaim perusahaan dan mencari alternative yang lebih unggul. Pelanggan cenderung memaksimalkan nilai dalam batasan biaya pencarian, pengetahuan, mobilitas, dan pendapatan. Pelanggan akan memperkirakan tawaran mana yang dapat memberikan nilai tertinggi yang akan membuat pelanggan bertindak atas dasar pemikiran tersebut. Sesuai atau tidaknya suatu penawaran dengan harapan akan mempengaruhi kepuasan pelanggan dan besarnya probabilitas bahwa pelanggan akan membeli produk itu lagi. Dengan demikian, nilai yang dirasakan pelanggan didasarkan pada selisih antara apa yang didapatkan pelanggan dan apa yang pelanggan berikan untuk kemungkinan pilihan yang berbeda.

Tjiptono (2004) menekankan bahwa pemasaran berkaitan erat dengan upaya menciptakan dan memberikan nilai kepada pelanggan. Nilai pelanggan merupakan sebuah konsep yang hingga saat ini paling digunakan oleh pelaku bisnis. Konsep ini pada dasarnya sederhana dan dapat digunakan sebagai langkah awal perumusan strategi selanjutnya. Secara sederhana, nilai pelanggan dapat didefinisikan sebagai semua manfaat atau kualitas yang diperoleh oleh konsumen relatif terhadap pengorbanannya. Nilai pelanggan biasa didefinisikan sebagai total manfaat atau kualitas dibagi harga. Kotler \& Armstrong (2001) mendefinisikan nilai pelanggan sebagai perbedaan antara nilai yang dinikmati pelanggan karena memiliki serta menggunakan suatu produk dan biaya untuk memiliki produk tersebut. Menurut Sweeney \& Soutar (2001), persepsi nilai pelanggan diklasifikasikan kedalam tiga dimensi yaitu nilai fungsional, nilai emosional, dan nilai sosial.

\section{Nilai fungsional}

Nilai fungsional adalah nilai yang diperoleh dari atribut produk yang memberikan kegunaan (utility) fungsional 
kepada konsumen nilai ini berkaitan langsung dengan fungsi yang diberikan oleh produk atau layanan kepada konsumen.

Nilai emosional

Nilai emosional adalah utilitas yang berasal dari perasaan atau efektif atau emosi positif yang ditimbulkan dari mengkon-sumsi produk. Jika konsumen mengalami perasaan positif (positive feeling) pada saat membeli atau menggunakan suatu merek, maka merek tersebut memberikan nilai emosional. Pada intinya nilai emosional berhubungan dengan perasaan, yaitu perasaan positif apa yang akan dialami konsumen pada saat membeli produk.

Nilai sosial

Nilai sosial adalah utilitas yang didapat dari kemampuan produk untuk meningkatkan konsep diri-sosial konsumen. Nilai sosial merupakan nilai yang dianut oleh suatu konsumen, mengenai apa yang dianggap baik dan apa yang dianggap buruk oleh konsumen.

Menurut Yang \& Peterson (2004), nilai pelanggan merupakan sebuah rasio dari manfaat yang didapat oleh pelanggan dengan pengorbanan. Perwujudan pengorbanan yang dilakukan oleh pelanggan sejalan dengan proses pertukaran adalah biaya transaksi, dan risiko untuk mendapatkan produk (barang dan jasa) yang ditawarkan oleh perusahaan. Ketika nilai yang dirasakan dari rasio yang dipersepsikan oleh pelanggan atas sejumlah pengorbanan ekonomi dengan produk yang ditawarkan perusahaan tidak sesuai dengan harapan pelanggan, maka akan memunculkan sikap tidak puas. Sebaliknya apabila sama atau melebihi harapan pelanggan maka pelanggan akan merasa puas.

Dewasa ini, konsep tujuan perusahaan telah bergeser dimana tujuan perusahaan tidak lagi semata-mata mencari laba, namun juga untuk memuaskan konsumen. Secara umum, kepuasan (satisfaction) adalah perasaan senang atau kecewa seseorang yang timbul karena membandingkan kinerja yang dipersepsikan produk (atau hasil) terhadap ekspektasi seseorang (Kotler \& Keller, 2009). Tjiptono (2008) mengungkap-kan bahwa kepuasan konsumen merupakan evaluasi purna beli di mana alternatif yang dipilih sekurangkurangnya memberikan hasil (outcome) sama atau melampaui harapan konsumen, sedangkan ketidak-puasan timbul apabila hasil yang diperoleh tidak memenuhi harapan konsumen. Kotler (2005), kepuasan konsumen adalah tingkat perasaan seseorang setelah membandingkan antara kinerja yang dirasakan dengan harapan. Konsumen yang tidak merasa puas atas kualitas dan pelayanan yang diperoleh cenderung menimbulkan masalah, sebaliknya apabila mereka puas maka akan tercipta hubungan yang baik dan harmonis. Hal ini akan menjadi dasar yang baik bagi terciptanya pembelian ulang dan terciptanya loyalitas konsumen yang akan menguntungkan perusahaan. Beralihnya konsumen disebabkan oleh kurang pekanya perusahaan dalam memberi pelayanan dan rasa tidak puas konsumen. Berdasarkan pengertian tersebut, maka dapat dinyatakan bahwa kepuasan konsumen adalah suatu tanggapan atau penilaian antara persepsi dan ekspektasi pembeli mengenai nilai suatu produk yang ditawarkan oleh produsen. Apabila kinerja berada di bawah harapan, maka konsumen akan kecewa. Sebaliknya, apabila kinerja sesuai dengan harapan, konsumen akan sangat puas.

Pembeli terpuaskan setelah membeli ataukah tidak sangat tergantung pada kinerja penawaran dalam hubungannya dengan ekspektasi pembeli. Begitu juga apakah pembeli mengintepretasikan adanya penyimpangan antara keduanya. Secara umum, kepuasan (satisfaction) adalah perasaan senang atau kecewa seseorang yang timbul karena membandingkan kinerja yang dipersepsikan produk (atau hasil) terhadap ekspektasi seseorang (Kotler \& Keller, 2009). Menurut Tjiptono (2008), kepuasan pelanggan adalah evaluasi purnabeli secara keseluruhan yang dilakukan pelanggan dengan membanding-kan persepsi atas kinerja produk dengan ekspektasi prapembelian.

Persepsi nilai pelanggan diyakini memberikan pengaruh terhadap tingkat kepuasan seorang pelanggan terhadap produk atau jasa yang akan digunakannya. 
Menurut (Yang \& Peterson, 2004), nilai pelanggan merupakan sebuah rasio dari manfaat yang didapat oleh pelanggan dengan pengorbanan. Menurut Sweeney \& Soutar (2001), persepsi nilai pelanggan diklasifikasikan kedalam tiga dimensi yaitu nilai emosional, nilai sosial, dan nilai fungsional. Hal ini sejalan dengan penelitian Luarn \& Lin (2003) yang menyatakan bahwa persepsi nilai memiliki hubungan yang positif dengan kepuasan konsumen. Penelitian Soegoto (2013), yang menyimpulkan bahwa persepsi nilai berpengaruh positip dan signifikan terhadap kepuasan konsumen. Rhee \& Ryu (2012) menemukan bahwa persepsi nilai memberikan kontribusi yang signifikan dalam mempengaruhi kepuasan konsumen. Yuriansyah (2013) menyatakan terdapat pengaruh persepsi nilaiproduk terhadap kepuasan pelanggan. Dan penelitian Choi \& Kim (2013) yang menyimpulkan bahwa persepsi nilai yang meliputi nilai fungsional, nilai emosional, dan nilai sosial berpengaruh positif dan signifikan terhadap kepuasan konsumen.

\subsection{Minat Beli Ulang}

Minat pembelian ulang merupakan penilaian individu tentang pembelian layanan kembali dan keputusan untuk terlibat dalam aktivitas masa depan dengan penyedia layanan dan bentuk yang akan diambil (Margee et al., 2008). Nilai untuk membeli kembali suatu produk atau jasa akan muncul ketika pelanggan merasa bahwa jasa yang diterimanya bisa memberikan kepuasan terhadap diri pelanggan tersebut. Bila pelanggan puas pada pembelian pertama, maka pembelian berikutnya cenderung akan dilakukan secara berulang-ulang pada satu merek, sehingga pengambilan keputusan tidak lagi diperlukan karena pelanggan telah mengetahui secara mendalam mengenai merek tersebut (Tatik, 2008). Sehingga dapat diambil kesimpulan bahwa pembelian ulang adalah suatu tindakan pelanggan untuk melakukan pembelian kembali setelah merasa puas atas pembelian yang semula.

Menurut Bigne et al (2001), minat berperilaku dikaji dari dua elemen yaitu return (keinginan pelanggan untuk kembali menggunakan layanan yang diberikan provider) dan recommend (keinginan pelanggan untuk memberikan rekomendasi pada pihak lain untuk mencoba layanan yang pernah dialaminya). Dalam konsep pembelian kembali ada dua konsep yang banyak dibahas yaitu intens membeli ulang (repurchase intentions) dan perilaku membeli ulang yang aktual (actual repurchase behavior).

Perilaku pembelian ulang seringkali dihubungkan dengan loyalitas. Menurut Tjiptono (2005), perbedaannya adalah, loyalitas mencerminkan komitmen psikologis terhadap merek atau produk tertentu, sedangkan perilaku pembelian ulang semata-mata menyangkut pembelian merek tertentu yang sama secara berulang kali. Pembelian ulang bisa merupakan hasil dominasi pasar oleh suatu perusahaan yang berhasil membuat produknya menjadi satusatunya alternatif yang tersedia. Konsekuensinya, pelanggan tidak memiliki peluang untuk memilih.

Pembelian ulang dapat pula merupakan hasil dari upaya promosi terusmenerus dalam rangka memikat dan membujuk palanggan untuk membeli kembali merek yang sama. Bila tidak ada dominasi pasar atau usaha promosi intensif tersebut, maka pelanggan bersangkutan mungkin beralih merek. Sebaliknya, pelanggan yang setia pada merek tertentu cenderung "terikat" pada merek tersebut dan akan membeli produk yang sama lagi sekalipun tersedia banyak alternatif lainnya.

Repurchase behavior dapat diukur melalui dua indikator yaitu (Sahin \& Kitapci, 2012) :

a. Repeat purchase intention : Repeat purchase intention adalah pembelian yang dilakukan dalam intens yang berulang. Dalam penelitian ini Repeat purchase intention adalah kondisi dimana konsumen memiliki tingkat intensitas akan kedatangan kembali.

b. Repurchase probability : Repurchase probability adalah suatu kemungkinan terjadinya pembelian kembali. Dalam penelitian ini maka Repurchase probability adalah kemungkinan yang 
dihadapi konsumen untuk datang kembali.

Berdasarkan uraian diatas, maka dapat diberikan beberapa hipotesis sebagai berikut :

H1a : Persepsi kualitas berpengaruh positif terhadap persepsi nilai fungsional

H1b : Persepsi kualitas berpengaruh positif terhadap persepsi nilai emosional

H1c : Persepsi kualitas berpengaruh positif terhadap persepsi nilai sosial

$\mathrm{H} 2 \mathrm{a}$ : Persepsi nilai fungsional berpengaruh positif terhadap kepuasan konsumen

$\mathrm{H} 2 \mathrm{~b}$ : Persepsi nilai emosional berpengaruh positif terhadap kepuasan konsumen

H2c : Persepsi nilai sosial berpengaruh positif terhadap kepuasan konsumen

H3 : Kepuasan konsumen berpengaruh positif terhadap minat pembelian ulang

Kerangka pemikiran pada model hipotesis yang telah diajukan dapat ditunjukkan dalam gambar berikut :

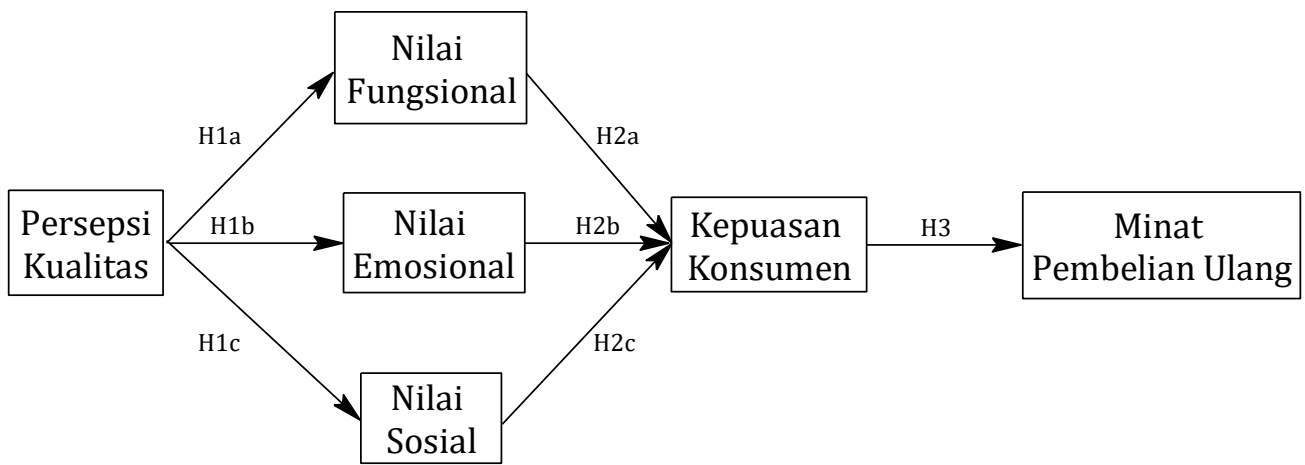

Gambar 2.1

Konseptual Model

Sumber : Choi \& Kim (2013)

\section{Metode Penelitian}

Windows.

Berikut hasil pengujian validitas dan reliabilitas dengan bantuan program SPSS 21.0 for

1. Hasil Uji Validitas

Kriteria pengambilan keputusan untuk menentukan valid, jika harga signifikan $r_{\text {hitung }}$ sama dengan atau lebih kecil dari harga signifikansi 0,05 maka butir instrumen yang dimaksud valid. Hasil uji validitas berdasarkan perhitungan dengan menggunakan SPSS for Windows 21.0 terhadap 30 responden penelitian adalah sebagai berikut:

Hasil Uji Validitas

\begin{tabular}{lcc}
\hline \multicolumn{1}{c}{ Variabel } & Signifikan r $_{\text {hitung }}$ & Keterangan \\
\hline Persepsi Kualitas & & \\
$\mathrm{PKP}_{1}$ & 0,000 & Valid \\
$\mathrm{PKP}_{2}$ & 0,000 & Valid \\
$\mathrm{PKP}_{3}$ & 0,000 & Valid \\
\hline $\mathrm{Nilai}$ Fungsional & & \\
$\mathrm{NF}_{1}$ & 0,000 & Valid \\
$\mathrm{NF}_{2}$ & 0,000 & Valid \\
$\mathrm{NF}_{3}$ & 0,000 & Valid \\
\hline $\mathrm{Nilai}$ Emosional & & \\
$\mathrm{NE}_{1}$ & 0,000 & Valid \\
$\mathrm{NE}_{2}$ & 0,000 & Valid \\
$\mathrm{NE}$ & 0,000 & Valid \\
\hline Nilai Sosial & & \\
\hline
\end{tabular}




\begin{tabular}{lcl}
\hline $\mathrm{NS}_{1}$ & 0,001 & Valid \\
$\mathrm{NS}_{2}$ & 0,000 & Valid \\
$\mathrm{NS}_{3}$ & 0,000 & Valid \\
\hline Kepuasan Pelanggan & & \\
$\mathrm{KP}_{1}$ & 0,000 & Valid \\
$\mathrm{KP}_{2}$ & 0,000 & Valid \\
$\mathrm{KP}_{3}$ & 0,000 & Valid \\
$\mathrm{KP}_{4}$ & 0,000 & Valid \\
\hline $\mathrm{Minat}$ Beli Ulang & & \\
$\mathrm{MBU}_{1}$ & 0,000 & Valid \\
$\mathrm{MBU}_{2}$ & 0,000 & Valid \\
$\mathrm{MBU}_{3}$ & 0,000 & Valid \\
\hline
\end{tabular}

Sumber : Data primer diolah, 2015.

Hasil uji validitas berdasarkan hasil perhitungan pada variabel persepsi kualitas, persepsi nilai yang meliputi nilai fungsional, nilai emosional, dan nilai sosial, kepuasan konsumen dan niat pembelian ulang dengan menggunakan SPSS 21.0 terhadap 30 responden dapat diambil kesimpulan bahwa semua pertanyaan dalam angket valid, karena memiliki nilai signifikan $r_{\text {hitung }}$ lebih kecil dari 0,05 , sehingga item pertanyaan dapat digumakan sebagai alat ukur yang cermat dan tepat dalam penelitian ini.

\section{Hasil Uji Reliabilitas}

Pengujian reliabilitas dalam penelitian ini dilakukan dengan menghitung besarnya nilai Cronbach'sAlpha instrumen dari masing-masing variabel penelitian yang diuji. Apabila nilai Cronbach's Coefficient Alpha lebih besar dari 0,6, maka item pertanyaan pada kuesioner sebagai alat pengukur dinyatakan reliabel. Hasil uji validitas berdasarkan perhitungan dengan menggunakan SPSS for Windows 21.0 terhadap 30 responden penelitian adalah sebagai berikut:

\begin{tabular}{|l|c|c|}
\multicolumn{1}{|c|}{ Variabel } & Cronbach's Alpha & Keterangan \\
\hline Persepsi kualitas & 0,789 & Reliabel \\
\hline Nilai fungsional & 0,780 & Reliabel \\
\hline Nilai emosional & 0,813 & Reliabel \\
\hline Nilai sosial & 0,610 & Reliabel \\
\hline Kepuasan konsumen & 0,820 & Reliabel \\
\hline Niat pembelian ulang & 0,695 & Reliabel \\
\hline
\end{tabular}

Sumber : Data primer diolah, 2015.

Berdasarkan hasil analisis diperoleh nilai koefisien cronbach's alpha untuk keempat variabel tersebut memiliki nilai koefisien cronbach's alpha lebih besar dari 0,6; maka kesimpulannya bahwa instrumen-instrumen penelitian tersebut reliabel dan dapat digunakan sebagai alat pengumpulan data sesungguhnya.

\section{Kesimpulan}

Berdasarkan pembahasan diatas, maka dapat diambil kesimpulan seperti dibawah ini :

1. Hipotesis dua yang meliputi tiga hipotesis menunjukkan bahwa semua hipotesis terbukti, yaitu : 1) Persepsi kualitas berpengaruh signifikan dan positif terhadap persepsi nilai fungsional; 2)
Persepsi kualitas berpengaruh signifikan dan positif terhadap persepsi nilai emosional; dan 3) Persepsi kualitas berpengaruh signifikan dan positif terhadap persepsi nilai sosial.

2. Selanjutnya pada hipotesis dua juga menunjukkan hasil yang sama, yaitu: 1) Persepsi nilai fungsional berpengaruh signifikan terhadap 
kepuasan konsumen; 2) Persepsi nilai emosional berpengaruh signifikan terhadap kepuasan konsumen; dan 3) Persepsi nilai sosial berpengaruh signifikan terhadap kepuasan konsumen.

3. Dan pada pengujian hipotesis tiga menunjukkan adanya pengaruh yang signifikan dan positif dari kepuasan konsumen terhadap minat pembelian ulang.

\subsection{Implikasi}

Hasil penelitian ini menunjukkan bahwa makin tingginya persepsi kualitas produk menjadikan tingginya persepsi nilai fungsional. Produk atau jasa yang berkualitas tentunya akan mempengaruhi cara pandang konsumen terhadap nilai produk/jasa tersebut. Hal ini berarti bahwa citra kualitas layanan yang baik bukanlah berdasarkan sudut pandang atau persepsi pihak penyedia jasa, melainkan berdasarkan pada sudut pandang atau persepsi konsumen. Seperti yang dikemukakan Kotler (2005) bahwa kualitas harus dimulai dari kebutuhan konsumen dan berakhir pada persepsi konsumen. Rangkuti (2003) menyatakan nilai produk sebagai pengkajian secara menyeluruh manfaat dari suatu produk, didasarkan persepsi pelanggan atas apa yang telah diterima oleh pelanggan dan yang telah diberikan oleh produk tersebut. Hasil penelitian ini sejalan dengan penelitian Adixio dan Saleh (2013) menunjukkan bahwa persepsi kualitas secara positif dan signifikan mempengaruhi nilai yang dipersepsikan. Hasil penelitian (Choi dan Kim, 2013) menyimpulkan bahwa persepsi kualitas berpengaruh positif dan signifikan terhadap persepsi nilai yang meliputi nilai fungsional.

Selanjutnya pelanggan cenderung memaksimalkan nilai dalam batasan biaya pencarian, pengetahuan, mobilitas, dan pendapatan. Pelanggan akan memperkirakan tawaran mana yang dapat memberikan nilai tertinggi yang akan membuat pelanggan bertindak atas dasar pemikiran tersebut. Sesuai atau tidaknya suatu penawaran dengan harapan akan mempengaruhi kepuasan pelanggan dan besarnya probabilitas bahwa pelanggan akan membeli produk itu lagi. Dengan demikian, persepsi nilai pelanggan diyakini memberikan pengaruh terhadap tingkat kepuasan seorang pelanggan terhadap produk atau jasa yang akan digunakannya. Menurut (Yang dan Peterson, 2004), nilai pelanggan merupakan sebuah rasio dari manfaat yang didapat oleh pelanggan dengan pengorbanan. Menurut (Sweeney dan Soutar, 2001), persepsi nilai pelanggan diklasifikasikan kedalam tiga dimensi yaitu nilai emosional, nilai sosial, dan nilai fungsional. Hal ini sejalan dengan penelitian Luarn dan Lin (2003) yang menyatakan bahwa persepsi nilai memiliki hubungan yang positif dengan kepuasan konsumen. Penelitian Soegoto (2013), yang menyimpulkan bahwa persepsi nilai berpengaruh positip dan signifikan terhadap kepuasan konsumen. Rhee and Ryu (2012) menemukan bahwa persepsi nilai memberikan kontribusi yang signifikan dalam mempengaruhi kepuasan konsumen. Yuriansyah (2013) menyatakan terdapat pengaruh persepsi nilaiproduk terhadap kepuasan pelanggan. Dan penelitian Choi dan Kim (2013) yang menyimpulkan bahwa persepsi nilai yang meliputi nilai fungsional, nilai emosional, dan nilai sosial berpengaruh positif dan signifikan terhadap kepuasan konsumen.

Dan hasil penelitian ini menunjukkan bahwa konsumen yang tidak merasa puas atas kualitas dan pelayanan yang diperoleh cenderung menimbulkan masalah, sebaliknya apabila mereka puas maka akan tercipta hubungan yang baik dan harmonis. Hal ini akan menjadi dasar yang baik bagi terciptanya pembelian ulang dan terciptanya loyalitas konsumen yang akan menguntungkan perusahaan. Terciptanya kepuasan konsumen dapat memberikan manfaat, diantaranya membentuk rekomendasi komunikasi lisan (Tjiptono, 2008). Konsumen akan membeli hanya dari satu pemasok dan menyebarkan berita yang baik tentang produk atau perusahaan melalui komunikasi, sehingga dapat dikatakan bahwa kepuasan konsumen dapat mempengaruhi minat pembelian ulang konsumen.

Hal ini sejalan dengan penelitian sebelumnya yang dilakukan oleh Adixio dan Saleh (2013) menunjukkan bahwa 
kepuasan pelanggan secara positif dan signifikan mempengaruhi minat pembelian kembali. Penelitian yang dilakukan oleh (Yu-Hui Fang et al, 2011), dimana kepuasan pelanggan berpengaruh signifikan terhadap minat pembelian ulang. Choi dan Kim (2013) menyimpulkan kepuasan konsumen memberikan pengaruh positif dan signifikan terhadap minat beli ulang. Penelitian Wisnalmawati (2005) menunjukkan hasil bahwa kepuasan berpengaruh terhadap minat pembelian ulang. Penelitian Tsiotsou (2005) menyatakan terdapat hubungan positif secara langsung antara kepuasan pelanggan dengan minat beli ulang terhadap berbagai kategori produk dan jasa. Dan hasil penelitian (Choi dan Kim, 2013) menyimpulkan bahwa kepuasan konsumen memberikan pengaruh positif dan signifikan terhadap minat beli ulang.

\subsection{Saran}

Saran yang dapat diberikan dari penelitian ini, antara lain:

1. Hasil penelitian menunjukkan bahwa persepsi konsumen atas nilai fungsional pada pembelian produkproduk yang dijual di Indomaret dirasakan dalam kategori cukup, untuk itu pihak manajemen untuk segera melakukan terobosanterobosan baru yang berkaitan langsung dengan fungsi yang diberikan oleh produk atau layanan kepada konsumen, karena hal ini berhubungan signifikan dengan niat pembelian ulang.

2. Masih kurang persepsi konsumen atas konsep diri-sosial konsumen jika berbelanja di Indomaret, untuk itu perlunya perbaikan-perbaikan atau inovasi dalam rangka meningkatkan presties yang dapat memberikan pengakuan sosial yang tinggi pada konsumen.

\section{DAFTAR PUSTAKA}

Adixio \& Saleh, 2013, Pengaruh Kualitas Layanan Dan Nilai Yang DirasakanTerhadap Niat Pembelian Ulang Melalui MediasiKepuasan Pelanggan Restoran Solaria Di Surabaya, Journal of Business and
Banking, Volume 3, No. 2, November, pages $151-164$.

Arikunto, 2006, Prosedur Penelitian Suatu Pendekatan Praktek. Jakarta: Rineka Cipta

Babin, 2004, Perceived Appropriateness And Its Effect On Quality, Affect And Behavior, Journal of Retailing and Consumer Services, 11, hal. 287-298.

Bigne, JE., Sanchez, MI., \& Sanchez, J., 2001, Tourism Image, Evaluation Variables And After Purchase Behavior: InterRelationship,Tourism Management. vol. 22, pp. 607-616

Butcher, K., 2005, Differential Impact of Social Influence in the Hospitality Encounter, International Journal ofContemporary

HospitalityManagement, Vol. 17 No. 2/3, pp. 125-135.

Choi, EJ \& Kim oo-Hyun, 2013, The Study of the Impact of Perceived Quality and Value of Social Enterprises on Customer Satisfaction and RePurchase Intention, International Journal of Smart Home, Vol. 7, No. 1, January.

Ghozali,I , 2006, Aplikasi Analisis Multivariate Dengan Program SPSS, Semarang : Badan Penerbit Undip 2011, Structural Equation Modeling Metode Alternatif Dengan Partial Least Square, Edisi 3, Badan Penerbit Universitas Diponegoro, Semarang.

Hellier, P.K., Geursen, G.M., Carr, R.A. and Rickard, J.A., 2003, Customer Repurchase Intention. A General Structural Equation Model, European Journal of Marketing, Vol. 37 No. 11/12, pp. 1762-1800.

Hicks, J.M., Page Jr, T.J., Behe, B.K., Dennis, J.H., Fernandez, R. And Thomas, 2005, Delighted Consumers Buy Again, Journal of Consumer Satisfaction, Dissatisfaction and Complaining Behaviour, Vol. 18, pp. 94-104.

Hurriyati, R, 2005, Bauran Pemasaran dan Loyalitas Konsumen, Cetakan Pertama, Penerbit: Alfabeta, Bandung.

Indrianto, N\& Supomo, B, 2002, Metodologi Penelitian Bisnis Untuk Akuntansi dan Manajemen.

Kotler Philip \& Amstrong, 2001, PrinsipPrinsip Manajemen, Jilid 1 Edisi 
Kedelapan, Alih Bahasa Oleh Damos Sihombing, MBA., Penerbit Erlangga, Jakarta.

Kotler, P, 2005, Manajemen Pemasaran: Analisis Perencanaan, Implementasi dan Pengendalian, Erlangga, Jakarta

Kotler, P\& Keller, Lane, Kevin,2009, Manajemen pemasaran, Edisi 13 Jilid 1. Jakarta.

Lovelock, C\& Wright, Lauren K, 2007, Manajemen Pemasaran Jasa, PT. Indeks, Indonesia.

Luarn, P\& Hsin-Hui lin, 2003, A Customer Loyalty Model For E Service Context,Journal of Electronic Commerce Research, Vol. 4, no. 4, p. 156-167.

Margee, H\& Gillian S. Mort, 2008, The Consequence Of Appraisal Emotion, Service Quality, Perceived Value And Customer Satisfaction On Repurchase Intent In The Performing Arts, Journal of Services Marketing, hal.170-182.

Puspitasari, D, 2006, Analisis Pengaruh Persepsi Kualitas Dan Kepuasan Pelanggan Terhadap Minat Beli Ulang (Studi Kasus pada Maskapai Penerbangan Garuda Keberangkatan Semarang, Tesis, Program Pasca Sarjana, Universitas Diponegoro, Semarang.

Rangkuti, F, 2003, Measuring Customer Satisfsction, Jakarta: PT Gramedia Pustaka Utama.

Rhee \&Min-Ji Ryu, 2012,Ability of Business Employee and Customer Satisfaction Research in the RelationshipModulating Effect of Purchasing Propensity. 3rd International Conference on e-Education, eBusiness, e-Management and eLearning IPEDR vol.27, IACSIT Press, Singapore.

Sahin Azize, Cemal Zehir, \& Hakan Kitapci, 2012, The Effects of Brand Experience,Trust, and Satisfaction on Building Brand Loyalty: An Empirical Research onGlobal Brands, International Strategic Management Conference, Elsiver Ltd.,Edition 7th, Procedia Social and Behavioral Science.

Scoot R. Swanson \& J. Charlene Davis., 2003, The Relationship of Differential
Loci With Perceived Quality and Behavioral Intention, Journal of ServiceMarketing, Vol. 17, No. 2, pp. 202-219.

Sugiyono, 2005, Metodologi Penelitian Bisnis, Cetakan Kelima, Penerbit Alfabeta, Bandung.

Soegoto, 2013, Persepsi Nilai dan Kepercayaan Terhadap Kepuasan dan Dampaknya Terhadap Loyalitas Konsumen. Vol 1, No 3 (2013): Jurnal EMBA, ISSN: 2303-1174. Diakses 21 November 2013. Hal 1193 - 1312.

Sweeny J. C. and Soutar G. N., 2001, Consumer-Perceived Value: The Development of a Multiple Item Scale, Journal of Retailing, Vol. 77, no. 2, pp. 203-220.

Tatik, S, 2008, Perilaku Konsumen : Implikasi pada Strategi Pemasaran, Edisi Pertama, Cetakan Pertama, Penerbit : Graha Ilmu, Jakart

Tjiptono, F, 2004. Manajemen Jasa, Andi. Yogyakarta 2008, Strategi Bisnis Pemasaran. Andi. Yogyakarta.

Tjiptono, F \& Chandra, G, 2005,Service, Quality \& Satisfaction, Penerbit ANDI, Yogyakarta

Tsiotsou, R., 2005, The Role Of Perceived Product Quality And Overall SatisfactionOn Purchase Intentions, International Journal of Consumer Studies, 30 , 2, March 2006, pp207-21.

Wisnalmawati, 2005, Pengaruh Persepsi Dimensi Kualitas Layanan Terhadap Niat Pembelian Ulang, Jurnal Ekonomi dan Bisnis, No. 3, Jilid 10, 153 - 165

Yang, Z \& Peterson, R.T., 2004, Customer Perceived Value, Satisfaction, and Loyalty: The Role of Switching Costs, Psychology and Marketing, Vol.21, pp 799-822

Yu-Hui Fang \& Chiu, CM, 2011, Understanding Customers Satisfaction and Repurchase Intentions: An Integration of IS Success Model, Trust and Justice, Internet Research. 21 (4): 479-503.

Yuriansyah, 2013, Persepsi Tentang Kualitas Pelayanan, Nilai Produk Dan Fasilitas Terhadap Kepuasan 
Pelanggan, Management Analysis Journal, ISSN 2252-6552

Wiyono, G., 2011, Merancang Penelitian

Bisnis Dengan Alat Statistik SPSS \&
SmartPLS, Unit Penerbit Dan

Percetakan STIM YKPN, Yogyakarta 